\title{
Passwords
}

Volume 13 | Issue 1

Article 4

$12-20-2012$

\section{Swollen River}

Natalie Dunn

Natalie_Dunn14@pitzer.edu

Follow this and additional works at: http://scholarship.claremont.edu/passwords

Part of the Art and Design Commons, Creative Writing Commons, and the Photography Commons

\section{Recommended Citation}

Dunn, Natalie (2012) "Swollen River," Passwords: Vol. 13: Iss. 1, Article 4. DOI: 10.5642/passwrd.20121301.04 Available at: http://scholarship.claremont.edu/passwords/vol13/iss1/4

This Poetry is brought to you for free and open access by the Journals at Claremont at Scholarship @ Claremont. It has been accepted for inclusion in

Passwords by an authorized administrator of Scholarship @ Claremont. For more information, please contact scholarship@cuc.claremont.edu. 


\section{Swollen River}

\section{Natalie Dunn}

I go once a year's worth of ice has drained into the swollen river and the fox beneath the house has found a new summer home. It's not where I was cut from my mother; it became a home after a friend, sixteen years, was crushed on the highway. It was violent, the taking. It was at first blood, organs, pavement-then it became something more real and it was when I was in the shower or driving by myself at night that I could see the red plastic car accident I've seen only through screens. It hurt like loneliness can or your mouth after swallowing cinnamon off a spoon. But when I'm in my kitchen and the light is skinny and I'm pulling sprigs of parsley from a pot in the windowsill (the faint bluish lights of the neighbor's television scatter squares across the walls and the squashes outside are beginning to burst flowers) — is when I'm reminded there's no world like the budding (and not yet bloomed).

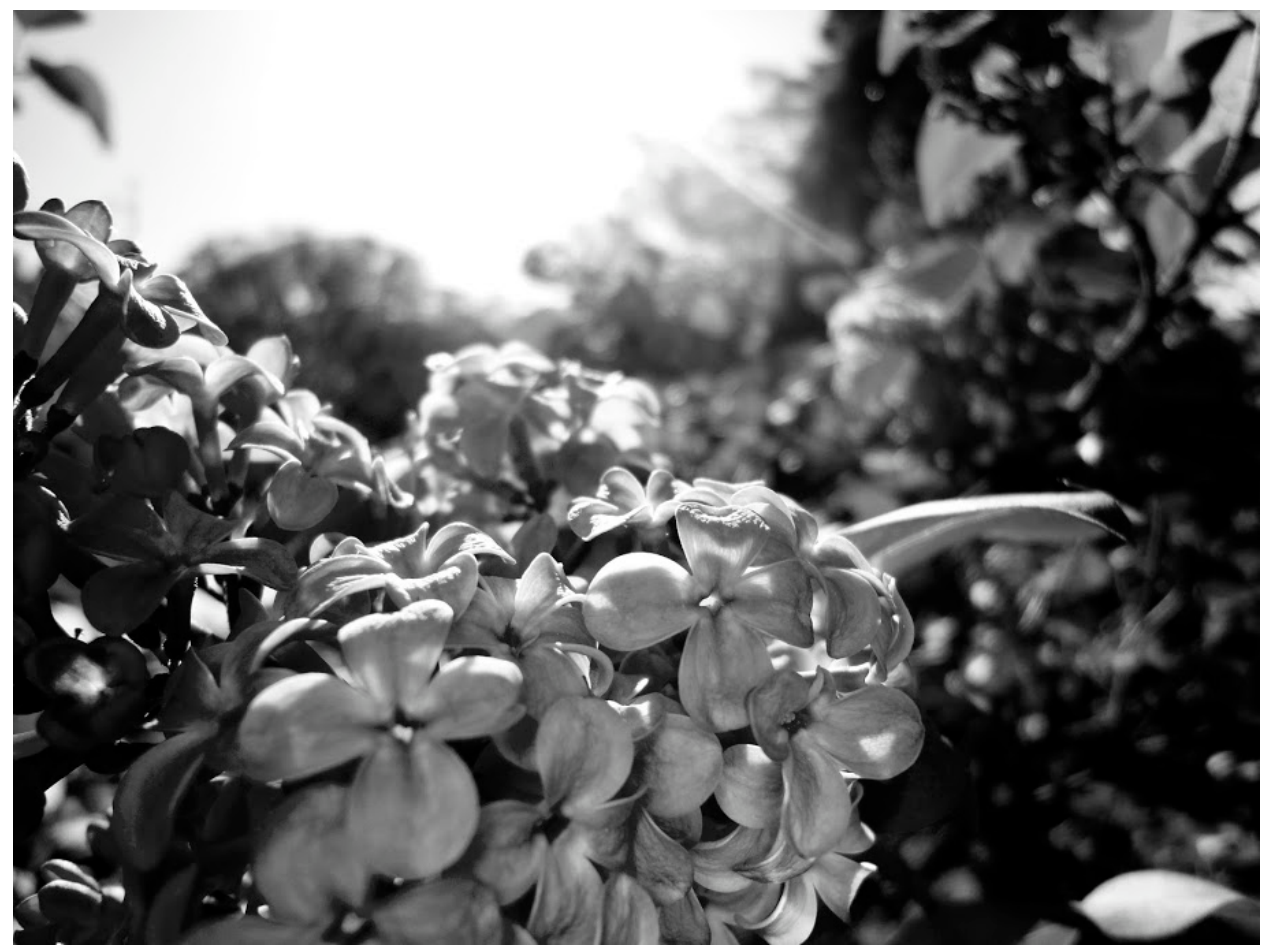

Rachel Davidson 